International Journal of Instruction

e-ISSN: 1308-1470 • www.e-iji.net

Article submission code:

20200109002725

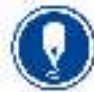

Received: 09/01/2020

Revision: 22/10/2020
April 2021 • Vol.14, No.2

p-ISSN: 1694-609X

pp. $811-830$

Accepted: 16/11/2020

OnlineFirst: 26/02/2021

\title{
Teachers Quality and Educational Equality Achievements in Indonesia
}

\section{Sekar Purbarini Kawuryan}

S. IP., M. Pd., Educational Sciences Doctoral Program, Graduate School, Universitas Negeri Yogyakarta, Indonesia, sekarpurbarini.2018@student.uny.ac.id

\section{Suminto A. Sayuti}

Prof., The Department of Indonesian Language and Literature, Faculty of Language and Arts, Universitas Negeri Yogyakarta, Indonesia, suminto_sayuti@uny.ac.id

\section{Aman}

Dr., M.Pd., The Department of Historical Education, Faculty of Social Sciences, Universitas Negeri Yogyakarta, Indonesia, aman@uny.ac.id

\section{Siti Irene Astuti Dwiningrum}

Prof., The Department of Philosophy and Sosiology of Education, Faculty of Education, Universitas Negeri Yogyakarta, Indonesia, siti_ireneastuti@uny.ac.id

Achieving equal learning opportunities for all students is a major policy goal in all countries. All children have the opportunity to obtain high quality education. Teachers become a key element in improving the quality of primary and secondary education This paper is based on secondary data information collected from various sources, namely policy documents that are relevant to research topics that still apply in Indonesia, national journal articles published starting in 2010-2020, reports from various government organizations, namely the Central Statistics Agency and the Ministry of Education and Culture, reports of international organizations, namely Worldbank and UNESCO, national and local newspapers published from 2015-2020, and websites. These data are triangulated, examined, and sought supporting evidence to improve the accuracy of research. Nationally, equality education in Indonesia as measured by expand access, equal access, and quality learning shows encouraging results, only a slight imbalance occurs between urban and rural schools.

Keywords: teacher quality, educational equality, educational achievement, Indonesia, teachers

\section{INTRODUCTION}

The issue of equality in education is a priority in all countries in the world, despite differences in constitutional arrangements, the level of socioeconomic development or geographical location (Burušić, Šakić, Babarović, \& Dević, 2013). Equality and access

Citation: Kawuryan, S. P., Sayuti, S. A., Aman., \& Dwiningrum, S. I. A. (2021). Teachers Quality and Educational Equality Achievements in Indonesia. International Journal of Instruction, 14(2), 811-830. https://doi.org/10.29333/iji.2021.14245a 
to education are key factors that determine the success of national development. Therefore, these two aspects become basic principles that are measured based on the success of their provision (Purnastuti \& Izzaty, 2016). Meanwhile, educational inequality tends to lead to other factors that interfere with the development of the health of school-age children. Thus, achieving equality of learning opportunities for all students becomes a major policy objective in all countries. All children have the opportunity to obtain high quality education (UNESCO, 2014).

Teacher quality plays an important driving force to improve student achievement and promote the economic competitiveness of a country in a global society. Improving teacher quality has been a major focus of education reform over the past 50 years (Akiba, LeTendre, \& Scribner, 2007). Characteristics of teacher quality associated with improving student learning achievement can be seen from several aspects, namely teacher certification, subject matter knowledge, pedagogical knowledge, and teaching experience (Darling-Hammond \& Youngs, 2002; Rice, 2003; Wayne \& Youngs, 2003; Wilson, Floden, \& Ferrini-Mundy, 2001, 2002). Knowledge of subject matter and pedagogical knowledge is measured by several indicators, namely main subjects, number of courses taken, and national teacher exam scores.

High-achieving countries, such as the United Kingdom, Hong Kong, Japan, Korea, the Netherlands, and Singapore have a centralized teacher education and certification system with tighter regulatory control by the central government, particularly in mathematics and education policy and eight-level teacher development (Wang, Coleman, Coley, \& Phelps, 2003). These countries, including Australia, use a number of screening criteria, namely enrolling in a teacher education program, evaluating field experiences, graduating from a teacher education program, or being certified. The system is different from the United States, which uses teacher licensure testing as the only main criterion for determining one's ability to be a teacher (Akiba, LeTendre, \& Scribner, 2007).

Teacher quality is a key element in improving the quality of primary and secondary education (Harris \& Sass, 2011), but achieving it according to criteria determined by each country as a whole is still difficult to realize. Some of the reasons include the gap between the number of teachers needed and the limitations of candidates, and the lack of teachers' ability to meet government requirements (Akiba, LeTendre, \& Scribner, 2007). The reason varies in different countries. In addition, the gap in urban and rural education in various countries is still happening today. Gaps are found not only in access to schools and infrastructure, but also in the quantity and quality of teachers. Teacher shortages become a national problem because schools face difficulties to retain high quality teachers (Ascher, 1991; Collins, 1999; Schwartzbeck et al., 2003). Some contributing factors include low salaries, isolated conditions, lack of housing, lack of infrastructure, the number of subjects being taught (Collins, 1999), and limited opportunities to attend competency improvement training (Collins, 1999; Monk, 2007).

Unfair student access to qualified teachers tends to play an important role in the longterm achievement gap (Darling-Hammond, 2006). Black and low-performing students, especially in poor urban and rural areas, disproportionately study with less qualified 
teachers (Darling-Hammond, 2000; Darling Hamond \& Bransford, 2005; Jerald, 2002; Lankford, Loeb, \& Wyckoff, 2002). In this context, teacher quality is the main source of inequality in student learning opportunities.

Indonesia's Human Development Index (HDI) ranks 116th out of 189 countries. This index reflects the quality of human capital as measured by indicators of the level of education, health, and purchasing power of the community. The Central Statistics Agency (BPS) recorded that the Indonesian HDI in 2019 was 71.92, higher than the 2018 HDI of 71.39 (Kontan, 2020). The increase in HDI is in line with improvements in life expectancy, quality of education, and people's purchasing power. Indonesia has succeeded in becoming a country with a high Human Development Index (HDI) in the Asia Pacific (Kompas, 2019). The improvement achieved by Indonesia is quite significant, but the problem of inequality is still insoluble. The problem of inequality is an obstacle that continues to be overcome and plays an important role for human growth throughout the world, especially Indonesia.

Descriptions of problems regarding teacher quality and student access gaps that occur in some of the above countries are also found in Indonesia. The quality of teachers in this context referred to the ownership of professional certificates. In 2017, out of 3.9 million teachers, $25 \%$ still did not meet the academic qualification requirements and $52 \%$ of teachers did not have professional certificates (Republika, 2019). In addition, internationally, the quality of basic education in Indonesia is still below the standard. Officials at all levels of government assume that a significant increase in funding is needed to improve education performance (Lewis, Pattinasarany, \& Sahn, 2011).

The Ministry of Education and Culture in 2019 has established 5 Missions, two of which are Mission 2 to realize broad, equitable and fair access, and Mission 3 to realize quality learning. Achievement indicators are limited to measures that can describe the situation of education in Indonesia. This paper focuses attention on broad access covering the ratio of students per class and class ratio per classroom, while the indicator of equal access is limited to continuing numbers. The education indicators for mission 3 cover student quality and teacher quality. Student quality is measured by repetition rates and survival rates for grade 5 (elementary) or junior and senior high schools. Teacher quality is focused on indicators of the percentage of teachers eligible to teach, and the student to teacher ratio. Therefore, this paper aims to answer research questions relating to the following educational equality achievements.

1. How are the achievement of Indonesian education based on expanding access?

2. How are the achievement of Indonesian education based on equal access?

3. How are the achievement of quality learning based on students and teachers aspects?

\section{METHOD}

This paper is based on secondary information collected from various sources, namely policy documents, journal articles, reports from various government organizations, reports from international organizations (Worldbank and UNESCO), information published in national and local newspapers, and on the website. The policy document 
utilized is a document that is relevant to the research topic which is still valid in Indonesia. National journal articles accessed are articles that have been published in the last 10 years, starting from 2010-2020, while national newspaper information has been utilized starting from 2015-2020. The data presented is official data published by the Central Statistics Agency (BPS). BPS is a Non-ministerial Government Institution that reports directly to the President. In addition, other supporting data sourced from the Ministry of Education and Culture which organizes affairs in the field of early childhood education, basic education, secondary education, and community education, and cultural management. Researchers use observation sheets to examine documents, examine all data sources, and look for evidence that supports the research topic. Various sources of data are then triangulated to improve the accuracy of the study. The data is analyzed qualitatively by summarizing it so that it can be understood and interpreted properly.

\section{FINDINGS}

\section{Achievement of Indonesian Education Based on Expanding Access}

Table 1

Number and ratios of students, study groups, and classrooms according to education level 2017/2018 academic year

\begin{tabular}{lllllrlr}
\hline $\begin{array}{l}\text { Education } \\
\text { Level }\end{array}$ & $\begin{array}{l}\text { Number of } \\
\text { Students }\end{array}$ & $\begin{array}{l}\text { Number of } \\
\text { Study } \\
\text { Group }\end{array}$ & $\begin{array}{l}\text { Number of } \\
\text { Classrooms }\end{array}$ & $\begin{array}{l}\text { Ratio } \\
\text { Student } \\
\text { Study Group }\end{array}$ & $\begin{array}{r}\text { of } \\
\text { Each }\end{array}$ & $\begin{array}{l}\text { Ratio of } \\
\text { Group } \\
\text { Classroom }\end{array}$ & $\begin{array}{r}\text { Study } \\
\text { Each }\end{array}$ \\
\hline $\begin{array}{l}\text { Elementary } \\
\text { school }\end{array}$ & 25486506 & 1115194 & 1072136 & 23 & 1.04 & \\
\hline $\begin{array}{l}\text { Junior } \\
\text { High } \\
\text { School }\end{array}$ & 10125724 & 358361 & 358361 & 28 & 1.00 & \\
\hline $\begin{array}{l}\text { Senior } \\
\text { High }\end{array}$ & 4783645 & 161071 & 160950 & 30 & & 1.00 & \\
School & & & & & & & \\
\hline Sources: BPS, Susenas & & & & & & \\
\hline
\end{tabular}

Sources: BPS, Susenas March 2018

Permendikbud Number 51 Year 2018 determines the maximum number of students per class for elementary schools was 28 , for junior high schools was 32 and for high school/vocational high school was 36 students. Table 1 shows that at the elementary level, an imbalance is found between the number of study groups and the number of classrooms. The total classrooms of 1072136 were used by study groups totaling 1115194. This means that some 43000 study groups did not have classes. 
Table 2

Expanding access from the top five provinces of elementary school levels in 2017/2018

\begin{tabular}{llll}
\hline Province & $\begin{array}{l}\text { Number of } \\
\text { Students }\end{array}$ & $\begin{array}{l}\text { Number of Study } \\
\text { Group }\end{array}$ & $\begin{array}{l}\text { Number of } \\
\text { Classrooms }\end{array}$ \\
\hline Jawa Barat & 4508356 & 161871 & 141721 \\
\hline Jawa Tengah & 2857363 & 127742 & 128968 \\
\hline Jawa Timur & 2838933 & 135190 & 135735 \\
\hline Sumatera Utara & 1735078 & 73917 & 71859 \\
\hline Sulawesi Selatan & 928029 & 45580 & 44348 \\
\hline
\end{tabular}

Source: publikasi.data.kemdikbud.go.id

Based on the data above, the largest number of classes is 161871 and the highest number of classrooms is 141721 in West Java Province

\section{Achievement of Indonesian Education Based on Equal Access}

Table 3

Continuing numbers

\begin{tabular}{|c|c|c|c|}
\hline & $\begin{array}{l}\text { Junior } \\
\text { School/Equivalent }\end{array}$ & High & $\begin{array}{l}\text { Senior } \\
\text { School/Equivalent }\end{array}$ \\
\hline Area Type & & & \\
\hline Urban & $94,39 \%$ & & $87,82 \%$ \\
\hline Rural & $92,48 \%$ & & $82,81 \%$ \\
\hline Gender & & & \\
\hline Male & $94,10 \%$ & & $85,08 \%$ \\
\hline Female & $92,77 \%$ & & $85,93 \%$ \\
\hline
\end{tabular}

Sources: BPS, Susenas March 2018

The continuing numbers provide information related to access or transition from one level of education to a higher level. Continuing numbers are also an indicator of output when viewed from the side of lower levels of education, and an indicator of inputs when viewed from the side of higher levels of education. In addition, the number of continuing school illustrates the selection by an education system due to scientific and economic factors. The differences in continuing numbers in rural and urban areas illustrate that there are still differences in the ease of access to education between the two.

Table 4

Equal access by continuing numbers to junior high schools from the top five provinces

\begin{tabular}{llll}
\hline Province & $\begin{array}{l}\text { Elementary School } \\
\text { Graduates }\end{array}$ & New Students & $\begin{array}{l}\text { Continuing } \\
\text { Numbers }\end{array}$ \\
\hline Bali & 66241 & 62820 & $94,84 \%$ \\
\hline Nusa Tenggara Timur & 123865 & 115364 & $93,14 \%$ \\
\hline DKI Jakarta & 133562 & 122652 & $91,83 \%$ \\
\hline DI Yogyakarta & 46797 & 42548 & $90,92 \%$ \\
\hline Kalimantan Utara & 11975 & 10806 & $90,24 \%$ \\
\hline
\end{tabular}


The highest continuing numbers to junior high schools is in the province of Bali at $94.84 \%$ with national figures at $81.50 \%$. Thus, the junior high school input only reached $81.50 \%$, which means that there were still $19.50 \%$ of elementary school graduates who did not continue to junior high school.

\section{Quality Learning Achievement for Students Aspect}

Table 5

Repeat number

\begin{tabular}{llll}
\hline Area Type & $\begin{array}{l}\text { Elementary } \\
\text { School/Equivalent }\end{array}$ & $\begin{array}{l}\text { Junior High School } \\
\text { /Equivalent }\end{array}$ & $\begin{array}{l}\text { Senior High } \\
\text { School/Equivalent }\end{array}$ \\
\hline Urban & 4,70 & 2,85 & 2,73 \\
\hline Rural & 4,62 & 3,55 & 3,43 \\
\hline
\end{tabular}

Sources: BPS, Susenas March 2018

Repeat number is defined as the proportion of students enrolled at a class level in a particular year and occupying the same class the following year.

Table 6

Survival numbers grade 5 elementary school/equivalent

\begin{tabular}{lc}
\hline & 5 Elementary School /Equivalent \\
\hline Area Type & \\
Urban & $94,57 \%$ \\
Rural & $94,32 \%$ \\
\hline Gender & \\
Male & $94,48 \%$ \\
Female & $94,43 \%$ \\
\hline
\end{tabular}

Sources: BPS, Susenas March 2018

Another indicator that can also illustrate the achievements of the educational process in Indonesia is the elementary/equivalent survival numbers which indicates the potential of a child entering elementary/equivalent to be able to survive up to the fifth grade. Elementary school/equivalent survival numbers are also used to monitor the implementation of universal primary education. Figures close to 100 indicate a high level of survival and low incidence of dropouts at the elementary school level/equivalent (UNESCO, 2009).

Table 7

Quality of elementary school students in the top five provinces based on repeat numbers

\begin{tabular}{lll}
\hline Province & Graduates & Repeat Numbers \\
\hline Jawa Barat & 740555 & $0,39 \%$ \\
\hline Bali & 66241 & $0,49 \%$ \\
\hline DKI Jakarta & 133562 & $0,54 \%$ \\
\hline Banten & 188965 & $0,79 \%$ \\
\hline DI Yogyakarta & 46797 & $0,90 \%$ \\
\hline
\end{tabular}

Source: publikasi.data.kemdikbud.go.id

The largest primary school graduates were in West Java Province with a total of 740555 and the smallest in North Kalimantan Province with a total of 11975. The highest 
number of elementary school repeats occurred in Central Java Province with a total of 53,440 and the smallest in North Kalimantan with a total of 1,620. The highest repeat numbers was in West Papua Province at $4.37 \%$ and the smallest was in West Java Province at $0.39 \%$ with a national average of $1.44 \%$.

\section{Quality Learning Achievement for Teachers Aspect}

Table 8

Teachers eligible to teach elementary and secondary education for the 2016/2017 and 2017/2018 academic year

\begin{tabular}{llll}
\hline Education Level & $\begin{array}{l}2016 / 2017 \\
\text { Academic Year }\end{array}$ & $\begin{array}{l}2017 / 2018 \\
\text { Academic Year }\end{array}$ & Percentage Increase \\
\hline Elementary School & $84.21 \%$ & $85.99 \%$ & $1.78 \%$ \\
\hline Junior High School & $92.11 \%$ & $93.16 \%$ & $1.05 \%$ \\
\hline Senior High School & $96.88 \%$ & $97.39 \%$ & $0.51 \%$ \\
\hline
\end{tabular}

Sources: BPS, Susenas March 2018

The academic qualifications of teaching staff in Indonesia can be seen through the level of the last education completed. Teachers in primary and secondary education must have a minimum academic qualification of four (D4) or undergraduate (S1) diplomas as stated in the Republic of Indonesia Ministerial Regulation No. 16/2007. The Ministry of Education and Culture defines teachers with educational qualifications as qualified teachers.

Meanwhile, when examined based on teacher competency test scores, there has been an increase in scores from 2014 to 2017, starting from the average of 40.7 points; 50.5 points; 60.49 points, and reached 80 points in 2017 (Kompas, 2017). Because the mean 80 is considered too heavy, adjustments are made. The target of the Ministry of Education and Culture in the 2018/2019 school year teacher competence test (UKG) results obtained an average score of 70 . Significant increase in value occurred in 2016, while the average rate for all levels of primary and secondary education until 2017 is still below 70. Even so, the increase in the percentage of teachers eligible to teach in Table 8 above has not been able to measure its quality because there are still other qualifications that need to be considered in relation to efforts to improve the quality of education.

Table 9

Number of students, teachers, and student-teacher ratios according to education level 2017/2018 academic year

\begin{tabular}{lccl}
\hline Education Level & Number of Students & Number of Teachers & Student-Teacher Ratio \\
\hline Elementary School & 25486506 & 1485602 & 17 \\
\hline Junior High School & 10125724 & 628052 & 16 \\
\hline Senior High School & 4783645 & 307751 & 16 \\
\hline
\end{tabular}

Sources: BPS, Susenas March 2018

The student-teacher ratio reflects the average number of students that are the responsibility of a teacher. The greater the student-teacher ratio, the smaller the student access to the teacher. This allows the teacher to pay more attention to students 
individually so as to support student achievement for the better. Article 17 Government Regulation Number 74 Year 2008 concerning Teachers states that at the elementary, junior high, high school levels, one teacher is ideally responsible for 20 students. Meanwhile, at the level of kindergarten, MI, MTs, MA 1 the teacher is ideally responsible for 15 students.

Table 10

Teacher quality in elementary schools in the top five provinces of 2017/2018 academic year

\begin{tabular}{lll}
\hline Province & Teacher Eligible & Student-Teacher Ratio \\
\hline Bali & $93,27 \%$ & 17 \\
\hline Jawa Tengah & $92,95 \%$ & 17 \\
\hline Jawa Timur & $92,76 \%$ & 15 \\
\hline DKI Jakarta & $92,74 \%$ & 22 \\
\hline Jawa Barat & $92,70 \%$ & 23
\end{tabular}

Source: publikasi.data.kemdikbud.go.id

The largest percentage of eligible teachers is in the province of Bali amounting to 93.27 and nationally to $81.32 \%$ including the "pratama" category.

\section{DISCUSSION}

\section{Access of Expanding Education in Indonesia}

Minister of Education and Culture Regulation (Permendikbud) Number 17 of 2017 states that the number of elementary school students is $20-28$ per study group (rombel). Table 1 above presents national student ratio per study group in primary schools, 23 children. This figure is considered quite difficult to achieve and causes inequality in a number of schools in several regions. For example, the number of registrants for new students at SDN Pagerwangi III in Lembang District, West Bandung Regency, West Java is still lacking. The number of students in all classes at this school is only around 120 children. This condition is very different from most schools that are higher than capacity, especially at the beginning of the registration of new students who meet up to 190 children (MediaIndonesia, 2017). Similar conditions also occur in Madura, East Java. Some schools that do not meet the class requirements due to too few students are planned to be merged (RadarMadura, 2017).

\section{Access of Equal Education in Indonesia}

The differences in numbers continue in rural and urban areas as presented in Table 3 above, illustrating the differences in access to education between the two countries. As an effort to improve quality checks, the Ministry of Education and Culture has rolled out a school zoning policy in 2017. Minister of Education and Culture Regulation No. 17 of 2017 concerning New Student Reception (PPDB) encourages increased access to education services 12 years, and increasing research priorities on the rich and the poor In the last three years, the government built 1,191 new schools, 239 one-roof schools, 52 boarding junior high schools, 22 dormitories for special education and special services. Affirmation of infrastructure facilities by 2017 has built 27,671 new classrooms, 4,649 
libraries, 6,419 practice rooms/laboratories, and 379 school health units (UKS). In addition, the government in cooperation with local governments has rehabilitated 67,253 learning spaces in various land areas (Kemdikbud, 2017).

Even so, the Indonesian Child Protection Commission (KPAI) in the Field of Education found 9 main problems that affected the adoption of the zoning system PPDB that occurred repeatedly in 2018 and 2019 (Wartakotalive, 2019). Based on PPDB, the zonations that must be addressed are as follows: (1) unequal distribution of public schools in each district and sub-district, while many regions base their zoning distribution on the administrative area of the sub-district; (2) Are prospective students not accommodated, because they cannot enroll in any school, while schools that are far from residential areas that lack students; (3) waiting in line until staying at school. This is not in accordance with the PPDB zoning policy and online system which ensures students in the zone closest to the school are definitely accepted; (4) the socialization of the PPDB system to prospective students and their parents is less structured, systematic and massive, so as to facilitate confusion; (5) readiness of the online registration infrastructure; (6) quota per zoning transition, including quota for study groups and capacity; (7) Choosing zoning spaces or changing rooms that do not involve the kelurahan; (8) unclear technical guidelines (technical guidelines); and (9) the number of unequal state schools in each sub-district so that the local government makes a policy of increasing the number of classes with 2 shift system (morning and afternoon). Disparities also occur in terms of student access to quality teachers.

\section{Quality Learning in Indonesia}

\section{Students Aspect}

This paper examines quality learning based on two main aspects, namely students and teachers. Student quality is measured based on repetition and survival numbers as the data presented in Table 5 and Table 6. Student achievement on both indicators is inseparable from the teacher's role.Teachers are the spearhead in efforts to improve the quality of services and educational outcomes (Kartowagiran, 2011), although many factors contribute to student success (Boyd, 2006; Rivkin, Hanushek, \& Kain, 2000; Sanders \& Horn, 1994). Student achievement depends on the readiness of the teacher to carry out learning activities that are supported by his knowledge, skills and attitudes (Tanang \& Abu, 2014). There is a significant difference in achievement between schools located in urban and rural areas, and schools in more economically developed areas are much more successful than schools in poorer regions (Burušić et al., 2013)

The academic achievement of students in developing countries who study in rural areas is lower (Mohd Burhan, 2005; Webster \& Fisher, 2000; Young, 1998) from much better urban areas (Charil, 1997; Hanushek, 1997; Sammons, 1999; Vegas, 2007). Table 5 shows that the difference in repetition numbers between urban and rural schools was only $0.08 \%$ at the elementary school level, $0.70 \%$ at the junior secondary level, and $0.30 \%$ at the senior secondary school level. The contributing factors are the lack of educational resources such as facilities, teaching materials, teacher quality, and teacher supply for each school (Vegas, 2007). The lack of teachers and other resources, 
combined with a limited population of students in rural areas, requires the combination of heterogeneous children in one class (Luschei \& Zubaidah, 2012), both in terms of age and abilities (McEwan, 1999). The effectiveness of teachers in teaching with high quality can foster positive effects of learning on students (Zumwalt \& Craig, 2005; Hill et al., 2007; Kennedy, Ahn, \& Choi, 2008). Characteristics of good teachers include general cognitive abilities and personalities (Wayne \& Youngs, 2003; Yeh, 2009; Zumwalt \& Craig, 2005) which provide benefits in education, such as student performance on standardized tests.

Other factors that challenge a teacher in teaching, in addition to cognitive challenges are also social and emotional (Jennings \& Greenberg, 2009). Teachers need to manage their involvement and develop ways to overcome these challenges in the long run (Kunter et al., 2013). Self-regulation in this context shows the ability to engage and simultaneously monitor a person's behavior in stressful situations and find ways to deal with it adaptively (Klusmann et al., 2008). Several types of teacher qualifications as described above affect student learning outcomes.

\section{Teachers Aspect}

Meanwhile, teacher quality is focused on the percentage of teachers eligible to teach based on their academic qualifications in Table 8, and the ratio of students to teachers in Table 9. Teachers become the central figure in improving the quality of education of a nation. Teacher qualifications as teaching staff play an important role in the learning process. Therefore, improvement of infrastructure as one of the determinants of the quality of education must be accompanied by the determination of the quality standards of the teaching staff. Teachers in developing countries face many challenges, including often working in classrooms with large numbers of students, poor buildings, inadequate facilities (Oplatka, 2007), which negatively impacts the quality of teaching and student achievement. Some of the difficulties faced by rural teachers in developing countries include, limited teaching resources, poor infrastructure, low-achieving students who are heterogeneous in age and ability, lack of training opportunities, isolation and security problems (McEwan, 1999). As a result of this difficulty, education officials often experience difficulties in recruiting teachers working in rural areas, which leads to significant quality differences between teachers in urban and rural areas.

Each country defines qualified teachers differently. Some aspects of quality teachers relate to the relationship between professional knowledge, teaching, and student achievement (Baumert et al., 2010), the relationship between beliefs and teaching (Dubberke et al., 2008), motivation with instruction (Kunter et al., 2008), and selfregulation with teaching (Klusmann et al., 2008). Qualified teachers exhibit certain cognitive characteristics, including following a careful recruitment and selection process so that they are successfully incorporated into this noble profession (Wayne \& Youngs, 2003; Yeh, 2009; Zumwalt \& Craig, 2005). In addition, measures of teacher qualifications also cover the level of preparation, level of experience, certification, background of mastery of content in the area taught, advanced level, selectivity of educational institutions, or test scores on college admissions and teacher licensing tests 
Darling-Hammond, 2000; Darling Hamond et al., 2005; Jerald, 2002; Lankford, Loeb, \& Wyckoff, 2002).

Many comparative studies have shown that the role of culture and teacher identity varies across countries (Anderson-Levitt, 2001; LeTendre, 1994, 1995; Shimahara \& Sakai, 1995; Welmond, 2002). National patterns of school organization and political priorities also influence the role and work approach of teachers in teaching (LeTendre, Baker, Akiba, Goesling, et al. 2001; Osborn et al., 2003). The quality of teachers in Indonesia in accordance with the mandate of Law Number 14 Year 2005 regarding Teachers and Lecturers is determined based on certification. This program aims to determine the appropriateness of the teaching profession in carrying out its duties as a learning agent and improving the process and quality of educational outcomes.

The data in Table 8 above shows that teachers who are eligible to teach nationally are appropriate if examined based on academic qualifications. However, if this is different if seen in each region. The sample of schools in the substitution areas of Jakarta also experienced a $66 \%$ shortage of teachers, compared to $68 \%$ oversupply in city schools (World Bank, 2008). Another example in West Java, five of the nine teachers at Madrasah Ibtidaiyah (MI), don't have an educational background. The five teachers are only high school graduates, three of whom in agreement are still in the 4th semester of PGSD majors (Republika, 2019). This condition is different from other elementary schools, where there are fourteen teachers with a bachelor's degree in education and one of them is pursuing a master's degree. However, these teachers don't want to develop themselves to increase knowledge and competence in teaching. The teachers get enough knowledge and knowledge possessed, never use learning media, and the method of lecture domination or assignment alone during learning. This is contrary to the Law on Teachers and Lecturers Article 20, namely in carrying out professional duties, a teacher is required to improve and develop academic qualifications and competencies that are supported, in accordance with the development of science, technology, and art.

Teacher professionalism is often associated with three important factors, namely competence, certification, and professional allowance. These three factors are predicted to affect the quality of education (Slameto, 2014). Several studies have proven that teacher competence has a positive and significant effect on student learning outcomes (Sutardi \& Sugiharsono, 2016), teacher professional competence has a positive and significant effect on teacher performance (Sopandi, 2019), teacher teaching performance, student satisfaction and achievement motivation gives significant contribution to student achievement (Suswanto, Asfani, \& Wibawa, 2017). In addition, teacher quality, especially teacher evaluation scores are statistically significant on student performance (Sirait, 2016). Educational professional qualifications are significant in teacher behavior and learning activities (Tanang et al., 2014). This is contrary to other research findings that teacher certification correlates very low with increasing professionalism and quality of learning (Koswara, Suryana, Triatna, 2009), teacher certification has no impact on student achievement (Fahmi, Maulana, \& Yusuf, 2011). Almost the same data was also found by Kartowagiran (2011) that the 
performance of most of the professional teachers (after certification) was not good, the efforts of most teachers who had passed the certification were still not encouraging.

Many teacher professional development programs have targeted management of classroom behavior, a positive emotional climate, and scaffolding for children's selfregulation to reduce behavioral problems (Yoshikawa et al., 2015). This class-based evaluation program has shown positive effects on the development of social and emotional functioning of preschoolers and elementary schools (Brown et al., 2010; Raver et al., 2009; Diamond et al., 2007; Webster-Stratton et al. , 2004). In addition, teacher education is an important program so that quality control and teacher certification contribute to its success (Brouwer \& Korthagen, 2005; Darling-Hammond et al., 2005; Kennedy et al., 2008). However, professional development does not have a positive effect on service productivity of primary school teachers (Jacob et al., 2004; Harris \& Sass, 2011) and is seen as ineffective (Jacob et al., 2004; Garet et al., 2008; 2010; Harris \& Sass, 2011). This ineffectiveness is likely due to teacher productivity focusing on specific contexts, such as curriculum and student characteristics.

Educational policies to ensure equality in education for all people and social groups alike in various countries. The difference lies in the activeness of realizing aspirations that divert in the equality of educational outcomes. Teacher workload is not directly on the quality of teaching and learning in class and can be done through ratios or counting the number of students with teachers as presented in Table 9 above. Worthy teachers include decent teachers who are not qualified to teach. This student-teacher ratio is often used to compare the quality of the education system between countries. However, this measure is weak if the interaction with differences in learning systems and the quality of education of each country. Comparison of high-resolution student-teacher ratios with high resolution and differences in class sizes at each level/class and the number of teaching hours. In addition, there are differences in the system of teaching staff, such as part-time teachers and the division of teaching shifts. Principals in Indonesia include in the calculation of student-teacher ratios, but often are not directly involved in the teaching and learning process.

Data on the number of students, teachers, and student-teacher ratios in Table 9 above have met the standards required by Government Regulation No. 74 of 2008 concerning Teachers. However, when compared with UNESCO (2014) provisions, Indonesia still cannot meet the criteria by agreeing to the 17:1. UNESCO won 26:1 for Asian countries, and 24:1 for middle-income countries. Schools in regions have a lower ratio than other regions. This proves the ineffectiveness of teacher workforce placement (Beritasatu, 2015). In addition, efforts to increase the number of student-teacher ratios have not been large against student learning outcomes. Limited opportunities to increase the education budget of the community must be balanced with more effective use of resources so that an increase in opportunities and quality of education can be created. Efforts to increase student-teacher ratios to achieve optimal learning outcomes.

Indonesia has the lowest student-teacher ratio in the world because of the existence of small schools in rural areas with fewer than 100 students. Teacher placement according to the rules of nine people per school is not effective because each teacher only guides 
1:10 students. This condition gave rise to the option to combine small schools in villages and cities aimed at increasing economies of scale from the aspect of teaching staff placement so that operational costs were reduced. The capacity building and analysis of Indonesian education must fit the needs of each function by ensuring a quality learning process. Teacher recruitment selection process improved. This can be started from the university which produces the best graduate teachers who excel, so that it can improve the quality of human resources and affect the quality of education. However, there are still many incompetent graduates who are recruited by the regions to fill the teacher gap due to uneven distribution (Beritasatu, 2015).

Unequal distribution of teachers can worsen inefficiencies and strengthen patterns of imbalance. In general, schools in rural and remote areas lack teachers, while schools in urban areas have more teachers than national standard staffing requirements. In addition, more qualified and more experienced teachers are generally concentrated in more affluent urban areas. The root cause of the unequal distribution of teachers is the reluctance of teachers to teach in poor and remote communities. This reluctance is driven by a number of factors, including regarding schooling for their own children, the availability of adequate housing, and the challenges of living in an unknown area. As a result, poor and remote areas usually have fewer teachers with lower qualifications than in urban areas. For example, more than half the number of elementary school and junior high school teachers in urban areas has a bachelor's degree, whereas only 20 percent of teachers in remote rural areas have a bachelor's degree (Worldbank, 2013). Equitable distribution of teachers by ensuring that poor and remote schools have a balanced percentage of qualified and experienced teachers can improve overall learning outcomes and reduce disparities.

The Ministry of Education and Culture (Kemendikbud) has provided an Affirmation service program to meet the needs of teachers in the regions. The program is carried out to overcome the problem of teacher shortages, especially in regions that are classified as frontier, outermost, and disadvantaged (3T). The affirmation program includes the Undergraduate Educating Program in the 3T Region (SM3T) and the Frontline Teacher Program (GGD), as well as Teachers who embrace in special areas (Kemdikbud, 2017). The SM3T program is an educational undergraduate service program to complete the acceleration of educational development in the $3 \mathrm{~T}$ area for one year. The program is carried out as a preparation for professional educators conducted by the Professional Teacher Education program. The Next Program GGD was carried out as an effort to check access to education by increasing the assistance of teaching staff in the 3T areas. The first batch of GGD program sent 798 professional teachers to 28 districts in $3 \mathrm{~T}$ areas spread over four provinces. The four provinces that the GGD program targets are Aceh, East Nusa Tenggara, Papua and West Papua. The Ministry of Education and Culture recruited 17,000 frontline teachers or GGDs to be placed in 15,000 villages, underdeveloped, frontier and outermost regions (3T). The teacher will hold the status of a prospective civil servant (CPNS) after graduating from the GGD program. The role of local government is needed to participate in implementing redistribution of teachers, increasing competence, and meeting teacher requirements that are still below the minimum standard. 
Some other programs that have also been implemented are Indonesia Teaching, the Indonesian Teachers School, the 1000 Teaching Teachers Movement, Teaching Teachers, and Teaching Scholars. Similar programs with variations in teacher status, teaching time, and activities during the $3 \mathrm{~T}$ area (lagging, outermost, outermost) are also still many, which pass the same, namely advancing the education of children in the 3T area. Distribution of areas visited during the implementation of this program from Sabang to Merauke.

\section{CONCLUSION}

The broader and equitable of educational access achievement, as well as quality learning in Indonesia nationally has been satisfactory. However, when examined in each region, there is still a lot of homework that must be completed by the Indonesian government. The success of educational development programs, especially in rural or remote areas, needs the support of educated communities. Therefore, the quality of teachers needs to be continuously improved with the support of adequate facilities and infrastructure so as to improve the quality of the process and learning outcomes. The limitations of this study only use six indicators based on the three variables measured, so that further research is needed.

\section{REFERENCE}

Akiba, M., LeTendre, G. K., \& Scribner, J. P. (2007). Teacher quality, opportunity gap, and national achievement in 46 countries. Educational Researcher, 36(7), 369-387. DOI: $10.3102 / 0013189 X 07308739$

Anderson-Levitt, K. (2001). Teaching culture. Cresskill, NJ: Hampton Press.

Baumert, J., Kunter, M., Blum, W., Brunner, M., Voss, T., Jordan, A., . . T Tsai, Y.-M. (2010). Teachers' mathematical knowledge, cognitive activation in the classroom, and student progress. American Educational Research Journal, 47, 133-180. doi:10.3102/0002831209345157

Boyd, D. J. et al. (2006). Complex by Design: Investigating Pathways into Teaching in New York City Schools. Journal of Teacher Education, 57(2), 155-166. http://dx.doi.org/10.1177/0022487105285943

Brouwer, C. N., \& Korthagen, F. (2005). Can teacher education make a difference? American Educational Research Journal, 42, 153-224. doi: $10.3102 / 00028312042001153$

Brown, J. L., Jones, S. M., LaRusso, M. D., \& Aber, J. L. (2010). Improving classroom quality: Teacher influences and experimental impacts of the 4Rs Program. Journal of Educational Psychology, 102, 153-167. http://dx.doi.org/10.1037/a0018160

Burušić, J., Šakić, M., Babarović, T., \& Dević, I. (2013). School Achievement in Urban and Rural Areas in Croatia: Is the quality of education equal for all? The International Handbook of Cultures of Education Policy: Comparative International Issuses in Policy- 
Outcome Relationship/Boufoy-Bastick, Béatrice(ur.). Strasbourg: Analytrics, 2013. str. $187-217$

Collins, T. (1999). Attracting and Retaining Teachers in Rural Areas (ERIC Digest). Charleston, WV: ERIC Clearinghouse on Rural Education and Small Schools. ERIC Document Reproduction Service No. ED438152.

Darling-Hammond, L. (2000). Teacher quality and student achievement: A review of state policy evidence. Educational Policy Analysis Archives, 8(1). Retrieved Dec 10, 2019, from http:// epaa.asu.edu/epaa/v8n1

Darling-Hammond, L. (2006). Securing the right to learn: Policy and practice for powerful teaching and learning. Educational Researcher, 35(7), 13-24.

Darling-Hammond, L., \& Bransford, J. (Eds.). (2005). Preparing teachers for a changing world: What teachers should learn and be able to do. San Francisco: Jossey-Bass.

Darling-Hammond, L., \& Youngs, P. (2002). Defining "highly qualified teachers": What does "scientifically-based research" actually tell us? Educational Researcher, 31(9), 13-25.

Diamond, A., Barnett, W. S., Thomas, J., \& Munro, S. (2007). Preschool program improves cognitive control. Science, 318, 1387-1388. http://dx .doi.org/10.1126/science. 1151148

Dubberke, T., Kunter, M., McElvany, N., Brunner, M., \& Baumert, J. (2008). Mathematics teachers' beliefs about teaching and learning: Effects on quality of instruction and student learning outcomes. Zeitschrift für Pädagogische Psychologie, 22, 193-206. doi: 10.1024/1010-0652.22.34.193

Fahmi, M., Maulana, A., \& Yusuf, A. A. (2011). Teacher Certification in Indonesia: A Confusion of Means and Ends. http://econpapers.repec.org/paper/unpwpaper/

Garet, M., Wayne, A., Stancavage, F., Taylor, J., Walters, K., Song, M., Brown, S., Hurlburt, S., Zhu, P., Sepanik, S., Doolittle, F. (2010). Middle school mathematics professional development impact study: findings after the first year of implementation. National Center for Education Evaluation and Regional Assistance, Institute of Education Sciences, U.S. Department of Education, NCEE, Washington DC. 2010 4009

Garet, Michael S., Cronen, Stephanie, Eaton, Marian, Kurki, Anja, Ludwig, Meredith, Jones, Wehmah, Uekawa, Kazuaki, Falk, Audrey, Bloom, Howard S., Doolittle, Fred, Zhu, Pei, Sztejnberg, Laura. (2008). The impact of two professional development interventions on early reading instruction and achievement. U.S. Department of Education, NCEE, Washington, DC. 2008-4031.

Hanushek, E.A. (1997). Assessing the effects of school resources on student performance: An update. Educational Evaluation and Policy Analysis, 19, 141-164. 
Harris, D. N., \& Sass, T. R. (2011). Teacher training, teacher quality and student achievement. Journal of Public Economics, 95(7-8), 798812. doi:10.1016/j.jpubeco.2010.11.009

Hill, H. C., Ball, D. L., Blunk, M., Goffney, I. M., \& Rowan, B. (2007). Validating the ecological assumption: The relationship of measure scores to classroom teaching and student learning. Measurement: Interdisciplinary Research and Perspective, 5, 107-118. doi:10.1080/ 15366360701487138

Jacob, Brian A., Lefgren, \& Lars. (2004). The impact of teacher training on student achievement: quasi-experimental evidence from school reform efforts in Chicago. Journal of Human Resources, 39(1), 50-79.

Jennings, P. A., \& Greenberg, M. T. (2009). The prosocial classroom: Teacher social and emotional competence in relation to student and classroom outcomes. Review of Educational Research, 79, 491-525. doi:10.3102/0034654308325693

Jerald, C. D. (2002). All talk, no action: Putting an end to out-of-field teaching. Washington, DC: Education Trust.

Kartowagiran, D. (2011). Kinerja guru profesional (guru pasca sertifikasi). Cakrawala Pendidikan, 30(3), 463-473.

Kennedy, M. M., Ahn, S., \& Choi, J. (2008). The value added by teacher education. In M. Cochran-Smith, S. Feiman-Nemser, D. J. McIntyre, \& K. E. Demers (Eds.), Handbook of research on teacher education (3rd ed., pp. $1249-1273$ ). New York, NY: Routledge.

Klusmann, U., Kunter, M., Trautwein, U., Lüdtke, O., \& Baumert, J. (2008). Teachers' occupational well-being and quality of instruction: The important role of self-regulatory patterns. Journal of Educational Psychology, 100, 702-715. doi:10.1037/00220663.100.3.702

Kunter, M., Klusmann, U., Baumert, J., Richter, D., Voss, T., \& Hachfeld, A. (2013). Professional Competence of Teachers: Effects on Instructional Quality and Student Development. Journal of Educational Psychology, 105(3), 805-820.

Kunter, M., Tsai, Y.-M., Klusmann, U., Brunner, M., Krauss, S., \& Baumert, J. (2008). Students' and mathematics teachers' perceptions of teacher enthusiasm and instruction. Learning and Instruction, 18, 468 - 482. doi:10.1016/j.learninstruc.2008.06.008

Lankford, H., Loeb, S., \& Wyckoff, J. (2002). Teacher sorting and the plight of urban schools: A descriptive analysis. Educational Evaluation and Policy Analysis, 24(1), $37-$ 62 .

LeTendre, G. (1994). Guiding them on: Teaching, hierarchy, and social organization in Japanese middle schools. Journal of Japanese Studies, 20(1), 37-59.

LeTendre, G. K. (1995). Disruption and reconnection: Counseling young adolescents in Japanese Schools. Educational Policy, 9(2), 169-184. 
LeTendre, G., Baker, D., Akiba, M., Goesling, B., \& Wiseman, A. (2001). Teachers' work: Institutional isomorphism and cultural variation in the U.S., Germany, and Japan. Educational Researcher, 30(6), 3-15.

Lewis, B. D., Pattinasarany, D., \& Sahn, D. E. (2011). The cost of public primary education in Indonesia: do schools need more money? Education Economics, 19(4), 397-410. doi:10.1080/09645290903358397

Luschei, T. F., \& Zubaidah, I. (2012). Teacher training and transitions in rural Indonesian schools: a case study of Bogor, West Java. Asia Pacific Journal of Education, 32(3), 333-350. doi:10.1080/02188791.2012.711241

McEwan, P.J. (1999). Recruitment of rural teachers in developing countries: An economic analysis. Teaching and Teacher Education, 15, 849-859.

Mohd Burhan, I. (2005). A hierarchical linear modeling of school effects and student factors affecting Penilaian Menengah Rendah (PMR) achievement (Unpublished doctoral dissertation). International Islamic University Malaysia, Kuala Lumpur, Malaysia.

Monk, D. H. (2007). Recruiting and Retaining High-Quality Teachers in Rural Areas. The Future of Children, 17(1), 155-174.

Oplatka, I. (2007). The context and profile of teachers in developing countries in the last decade: A revealing discussion for further investigation. International Journal of Educational Management, 21, 476-490.

Osborn, M., Broadfoot, P., McNess, E., Planel, C., Ravn, B., \& Triggs, P. (2003). A world of difference? Comparing learners across Europe. Maidenhead, UK: Open University Press.

Purnastuti, L., \& Izzaty, R. E. (2016). Access and Equity in Higher Education in Indonesia: A Review from the Periphery. Widening Higher Education Participation, 119-134. doi:10.1016/b978-0-08-100213-1.00008-1

Raver, C. C., Jones, S. M., Li-Grining, C., Zhai, F., Metzger, M. W., \& Solomon, B. (2009). Targeting children's behavior problems in preschool classrooms: A clusterrandomized controlled trial. Journal of Consulting and Clinical Psychology, 77, 302316. http://dx.doi.org/10.1037/a0015302

Rivkin, S. G., Hanushek, E. A., \& Kain, J. F. (2000). Teachers, schools, and academic achievement (Working Paper W6691). Cambridge, MA: National Bureau of Economic Research.

Sammons, P. (1999). School effectiveness: Coming of age in the twenty-first century. Lisse, The Netherlands: Swets \& Zeitlinger.

Sanders, W. L., \& Horn, S. P. (1994). The Tennessee Value-Added Assessment System (TVAAS): Mixed-model Methodology in Educational Assessment. Journal of Personnel Evaluation in Education, 8, 299-311. http://dx.doi.org/10.1007/BF00973726 
Schwartzbeck, T. D., Prince, C. D., Redfield, D., Morris, H., \& Hammer, P. C. (2003). How Are Rural School Districts Meeting the Teacher Quality Requirements of No Child Left Behind? Retrieved from https://aasa.org/uploadedFiles/Policy_and_Advocacy/files/RuralTeacherQualityStudy.p df

Shimahara, N., \& Sakai, A. (1995). Learning to teach in two cultures. New York: Garland.

Sirait, S. (2016). Does Teacher Quality Affect Student Achievement? An Empirical Study in Indonesia. Journal of Education and Practice, 7(27), 34-39. Available at SSRN: https://ssrn.com/abstract=2846795

Slameto. (2014). Permasalahan-permasalahan terkait dengan profesi guru SD. Scholaria, 4(3), 1-12.

Sopandi, A. (2019). Pengaruh kompetensi profesional dan kompetensi kepribadian terhadap kinerja guru. Scientific Journal of Reflection: Economic, Accounting, Management and Business, 2(2), 121-130.

Suswanto, H., Asfani, K., \& Wibawa, A. P. (2017). Contribution of teaching performance, learning satisfaction and achievement motivation to students' competence achievement. Global Journal of Engineering Education, 19(1), 66-71.

Sutardi \& Sugiharsono. (2016). Pengaruh Kompetensi Guru, Motivasi Belajar, dan Lingkungan Keluarga Terhadap Hasil Belajar Mata Pelajaran Ekonomi. Harmoni Sosial: Jurnal Pendidikan IPS, 3(2), 188-198

Tanang, H., \& Abu, B. (2014). Teacher Professionalism and Professional Development Practices in South Sulawesi, Indonesia. Journal of Curriculum and Teaching, 3(2), 2542. http://dx.doi.org/10.5430/jct.v3n2p25

Tanang, H., Djajadi, M., Abu, B., \& Mokhtar, M. (2014). Challenges of Teaching Professionalism Development: A Case Study in Makassar, Indonesia. Journal of Education and Learning. 8(2), 132-143.

UNESCO. (2014). EFA Global Monitoring Report 2013/4 - Teaching and Learning: Achieving Quality for All. UNESCO, Paris.

Vegas, E. (2007). Teacher labor markets in developing countries. Future of Children, $17,219-232$.

Wang, A. H., Coleman, A. B., Coley, R. J., \& Phelps, R. P. (2003). Preparing teachers around the world. Princeton, NJ: Educational Testing Service.

Wayne, A. J., \& Youngs, P. (2003). Teacher characteristics and student achievement gains: A review. Review of Educational Research, 73(1), 89 -122. doi:10.3102/00346543073001089

Webster, B.J., \& Fisher, D.L. (2000). Accounting for variation in science and mathematics achievement: A multilevel analysis of Australian data - Third International 
Mathematics and Science Study (TIMSS). School Effectiveness and School Improvement, 11, 339-360.

Webster-Stratton, C., Reid, M. J., \& Hammond, M. (2004). Treating children with earlyonset conduct problems: Intervention outcomes for parent, child, and teacher training. Journal of Clinical Child and Adolescent Psychology, 33, 105-124. http://dx.doi.org/10.1207/ S15374424JCCP3301_11

Wilson, S. M., Floden, R. E., \& Ferrini-Mundy, J. (2001). Teacher preparation research: Current knowledge, gaps, and recommendations. Seattle, WA: Center for the Study of Teaching and Policy.

World Bank (2008). Teacher employment and deployment in Indonesia. Jakarta: Indonesia World Bank Office

World Bank. (2013). Mendayagunakan Guru dengan Lebih Baik: Memperkuat Manajemen Guru untuk Meningkatkan Efisiensi dan Manfaat Belanja Publik. Naskah Kebijakan. Diakses dari http://documents.worldbank.org/curated/en/704271468044660179/pdf/741550BRIOIND O00Box377384B00PUBLIC0.pdf

Yeh, S. S. (2009). The cost-effectiveness of raising teacher quality. Educational Research Review, 4, 220 -232. doi:10.1016/j.edurev.2008.06 .002

Yoshikawa, H., Snow, C. E., Barata, M. C., Gomes, C. J., Leyva, D., Trevino, E., Weiland, C., Moreno, L., Rolla, A., D'Sa, N., \& Arbour, M. C. (2015). Experimental Impacts of a Teacher Professional Development Program in Chile on Preschool Classroom Quality and Child Outcomes. Developmental Psychology, 51(3), 309 -322. http://dx.doi.org/10.1037/a0038785

Zumwalt, K., \& Craig, E. (2005). Teachers' characteristics: Research on the indicators of quality. In M. Cochran-Smith \& K. M. Zeichner (Eds.), Studying teacher education: The report of the AERA Panel on Research and Teacher Education (pp. 157-260). Mahwah, NJ: Erlbaum

BPS, Susenas Maret 2018.

berkas.dpr.go.id > public-file > infografis-public-49

https://republika.co.id/berita/pq53k5368/rendahnya-kompetensi-guru-jadi-masalahpendidikan-indonesia

https://www.beritasatu.com/nasional/273803-acdp-rasio-guru-dan-murid-di-indonesiatimpang

https://nasional.kontan.co.id/news/indeks-pembangunan-manusia-indonesia-tahun-2019naik-menjadi-7192

https://money.kompas.com/read/2019/12/10/190621026/undp-untuk-pertama-kalinyaipm-indonesia-masuk-kategori-tinggi?page=all. 
https://mediaindonesia.com/read/detail/111584-sejumlah-sd-kekurangan-siswapermendikbud-sulit-diterapkan 